\title{
Characteristics of Preterm Birth Cases at Sanglah Hospital Denpasar (Period from 1 January to 31 December 2016)
}

\author{
I Made Pasek Soma Gauthama ${ }^{1}$, I Ketut Surya Negara ${ }^{2}$ \\ ${ }^{1,2}$ Department of Obstetrics and Gynecology Obstetrics Medical Faculty Udayana University/ Sanglah Hospital Denpasar
}

\begin{abstract}
Background: Preterm labor is a major cause of death and an important cause of congenital disabilities. According to WHO, preterm delivery is a labor that occurs between 20 weeks' gestation to less than 37 weeks, calculated from the first day of the last menstrual on a 28-day cycle. This study aims to determine the characteristics of pregnancy and preterm delivery at Sanglah Hospital during the year 2016. Methods: This is a retrospective research using descriptive methods; data were taken from Sanglah Hospital medical record. All cases of preterm labor in Sanglah Denpasar Hospital delivery room from 1 January to 31 December 2016 were used, information starting from the initial diagnosis at admission and the patient's medical record number were also recorded. Data were then processed with tabulation method in accordance with the characteristics of preterm labor cases. The results data were then analyzed descriptively using SPSS 16 software. Results \& Discussions: The results showed that within 1 year from 1 January to 31 December 2016, from all deliveries, there was 195 (18.6\%) preterm birth cases in midwifery Sanglah Denpasar Hospital. Preterm labor was most common at the age of 20-35 years old (77.9\%), at the age of pregnancy 32 to $<37$ weeks (67.6\%). Preterm birth occurs highest in mothers with primigravida (42.5\%). This research also found that in 22 cases with preterm birth, previously had experienced preterm labor, where 19 cases $(9.7 \%)$ had 1 preterm delivery, and 3 cases (1.5\%) had a history of 2 previous preterm deliveries. Based on medical history experienced by a mother with preterm delivery at Sanglah Hospital Denpasar, 49 (25.1\%) had hypertension in pregnancy. Babies born preterm in Sanglah Denpasar Hospital period 1 January to 31 December 2016 most had a birth weight between 1500 to <2500 grams, where 150 babies (70\%) was born with vigorous counts. There were 167 infants (78\%) who were preterm born in Sanglah Denpasar Hospital from January 1 to December 312016 treated with joint care, and the remaining 29 (13.5\%) were admitted to the Neonatal Intensive Care Unit (NICU). Conclusions: This research is a preliminary study that can be used as reference data about the characteristics of preterm labor in obstetrics and gynecology Sanglah Hospital Denpasar Periode January 1 to December $31,2016$. Given the importance of these data, this study may be used as basic data to do a continuous research, to find out all other characteristics. Also to find the occurrence of preterm labor and its complications, so in the near future can be used as a consideration for the management of preterm labor, also reduce and anticipate complications that could happen.
\end{abstract}

Keywords: Labor, preterm, characteristics

\section{Introduction}

Preterm labor is one of the important causes of perinatal morbidity and mortality in developing countries and in referral hospitals. This is a serious concern because up to now the incidence is still high despite various attempts made to reduce its occurrence. Preterm delivery is responsible for approximately $35 \%$ of the 3.1 million infant deaths per year and the second most common cause of death in children under 5 years after pneumonia. Preterm labor is a major cause of death and a notable cause of birth defects in infants worldwide. Prenatal labor complications are the direct and most common cause of neonatal death. ${ }^{1}$ Preterm births also increase the risk of infants dying due to other causes, especially neonatal infections, with an estimated $50 \%$ of all perinatal deaths. ${ }^{1}$

Recent reports in the United States of America, preterm labor contributes more than $12 \%$ of normal births. This problem is also significant in the European population, where preterm delivery increased by more than $50 \%$ in lowrisk primiparous women in the last decade. ${ }^{2}$ The increase primarily occurs at 32 to 37 gestational weeks. Estimated number of preterm births in these countries in 1990 was 2 million, this number increased to 2.2 million in 2010. In 2010, about 15 million babies were born prematurely, more than 1 million died due to complications experienced in the first month of birth, and many others suffered growth disorders.

In developing countries, the incidence rate is much higher, for example in India about $30 \%$, South Africa 15\%, and Sudan $31 \%$. Unfortunately, the preterm birth rates in Indonesia is still unavailable, but the national birth rate of low birth weight (LBW) of hospitals reaches $27.9 \%$ in the last 10 years, in which LBW can served as a rough indication of preterm delivery. ${ }^{3}$ Based on WHO data in 2010, Indonesia ranks 5th out of 10 countries for the highest number of preterm births, and 9th out of 11 countries for countries with the most numerous preterm delivery. ${ }^{1}$

Based on the Regency / City profile in 2011, the lowest number of infant mortality rate(IMR) was in Denpasar (1.78 per 1000 live birth), Badung Regency (4.93 per 1000 live birth), and Buleleng Regency (5.97 per live birth), while the highest IMR was In Jembrana District (14.08 per 1000 live birth) and Klungkung Regency (11.80 per 1000 live birth) ${ }^{4}$ In general, the most frequent causes of preterm labor include stress, maternal genital tract or systemic infection, placental ischemia or vascular lesions, and excessive stretching of the uterus. When viewed from the triggering factors and mediator, all seems to have different causes but they all cause the same end result of uterine contractions and labor. The authors are interested in conducting a descriptive research to determine the characteristics of preterm 


\section{International Journal of Science and Research (IJSR) \\ ISSN (Online): 2319-7064}

Index Copernicus Value (2015): 78.96 | Impact Factor (2015): 6.391

pregnancy and delivery at Sanglah Hospital during the year 2016.

\section{Methods}

This study is a retrospective descriptive study at Sanglah Hospital during the period of 1 January to 31 December 2016. The inclusion criteria are all preterm mothers and babies in Sanglah Hospital Denpasar. The initial stage is to collect data of labor with preterm pregnancy from birth register book and newborn register in delivery room of Sanglah Hospital Denpasar. From these data, the initial diagnosis on admission is obtained and patient medical record number is retrieved. With the number, the medical record of Sanglah Hospital is searched in accordance with the initial data from the register book. The required characteristic data obtained were then and eventually processed with SPSS software for descriptive analysis.

\section{Results and Discussion}

During the 1 year period from 1 January to 31 December 2016, the total number of deliveries was 1044 and preterm delivery in obstetrics and gynecology department of Sanglah Hospital Denpasar as many as 195 cases (18.6\%). This amount is relatively high when compared to the variation of preterm delivery incidents in several countries around the world. A report by Blencowe et $\mathrm{al}^{6}$ in 2010 revealed $13.5 \%$ preterm birth rate in Southeast Asia and Oceania. The characteristics of preterm labor in delivery room of Sanglah Hospital Denpasar in 2016 are as follows.

\section{Characteristics of Preterm Birth by Maternal Age}

The spread of preterm labor cases based on maternal age in this study can be seen in the following table:

Table 1: Distribution of Preterm Delivery by Maternal Age at RSUP Sanglah Denpasar period 1 January - 31 December

\begin{tabular}{|c|c|c|}
\hline \multicolumn{3}{|c}{2016} \\
\hline Age (year-old) & $\mathbf{N}$ & $\mathbf{\%}$ \\
\hline $15-19$ & 12 & 6.1 \\
\hline $20-35$ & 152 & 7.9 \\
\hline $36-45$ & 31 & 15.8 \\
\hline Total & $\mathbf{1 9 5}$ & $\mathbf{1 0 0}$ \\
\hline
\end{tabular}

In this study it was found that the incidence of preterm labor was most common in the age group of 20 to 35 years ie 152 cases $(77.9 \%)$. A study conducted by the Centers for Disease Control and Prevention (CDC) on maternal age and incidence of preterm labor in 2008 in the United States found the most common age for preterm labor occurred in women $<20$ years and $>35$ years old, mothers between 20 34 years old had lower risk. Increased risk of preterm delivery in older women is associated with the prevalence of comorbidities such as diabetes and hypertension, high rate of preterm delivery also found in women with multiple pregnancies after undergoing reproductive assisted programs. At a younger age, the increased risk of preterm labor is due to immature biological organs, low economic status and behavioral risk factors such as smoking. The age of the youngest mother with preterm delivery at Sanglah Hospital during 1 January - 31 December 2016 period is 15 years old and the oldest age was 45 year-old.
Characteristics of Preterm Delivery by Age of Pregnancy The case of preterm labor is divided into three groups: extreme preterm, very preterm, and moderate preterm.

Table 2: Distribution of Preterm Delivery by Age of Pregnancy at Sanglah Denpasar Hospital period 1 January 31 December 2016

\begin{tabular}{|c|c|c|}
\hline Delivery Age (weeks) & $N$ & $\%$ \\
\hline Extreme preterm $(<28$ weeks) & 16 & 8.2 \\
\hline Very preterm $(28$ up to $<32$ weeks $)$ & 47 & 24.1 \\
\hline Moderate preterm $(32$ up to $<37$ weeks) & 132 & 67.6 \\
\hline Total & $\mathbf{1 9 5}$ & $\mathbf{1 0 0}$ \\
\hline
\end{tabular}

From these data, preterm birth incidence based on gestational age was most prevalent in 32 weeks of gestational age group until <37 weeks (moderate preterm) as many as 132 cases $(67.6 \%)$. Research conducted by Butali et al in 2015 obtained preterm labor rates in Nigeria of $4.7 \%$ in early preterm (22-31 weeks), $4.5 \%$ in moderate preterm (3234 weeks), and $7.7 \%$ in late preterm (35-36 weeks). ${ }^{7}$

\section{Characteristics of Preterm Labor by Type of Labor}

From 195 cases of preterm labor, the most frequently performed method of delivery was vaginal delivery with 115 cases $(58.9 \%)$. The operative vaginal delivery in Sanglah General Hospital used forcep extraction in as much as 17 cases $(8.75 \%)$ and perabdominal delivery through sectio caesarea was performed in 63 cases $(63.3 \%)$. In contrast to research conducted by Halimi in 2015 in Tehran, Iran, it was found that preterm birth rate through vaginal delivery was $43 \%$ while perabdominal delivery or through sectio caesarea was as much as $57.2 \% .^{8}$ The most frequent indications for cesarean delivery was fetal distress and antepartum Bleeding of 12 cases each (19\%), followed by hypertension in pregnancy and breech position of 8 cases $(12,6 \%)$ and 7 cases $(11,1 \%)$ respectively, with indication of former cesarean section. Indications of caesarean section due to eclampsia and gemelli were $5(7.9 \%)$ and 2 cases $(3.1 \%)$ respectively in horizontal breech and HIV cases.

Table 3: Distribution of Preterm Labor by Type of Birth at RSUP Sanglah Denpasar period 1 January - 31 December

\begin{tabular}{|c|c|c|}
\multicolumn{3}{|c}{2016} \\
\hline Methods of delivery & $\mathbf{N}$ & $\%$ \\
\hline Spontaneous pervaginam & 115 & 58.9 \\
\hline Operation pervaginam & 17 & 8.7 \\
\hline Perabdominal & 63 & 32.3 \\
\hline Total & $\mathbf{1 9 5}$ & $\mathbf{1 0 0}$ \\
\hline
\end{tabular}

\section{Characteristics of Preterm Labor Based on Gravida}

Based on gravida, the highest preterm labor rates in maternity ward of Sanglah Hospital during 2016, were found in primigravida with as much as $42.5 \%$, second gravida was $28.2 \%$, third gravida was $18.4 \%$, and fourth or more gravida was as much as $10.7 \%$. A study conducted by Broek et al in 2009 in Malawi, where the incidence of preterm labor was more prevalent in multigravida women was $57.2 \%$ compared with primigravida of $36.3 \% .^{9}$ In another study, it was said that nulliparous women had lower gestational age compared with multiparous women $(32.2 \pm 0.2$ versus $33.0 \pm 0.1$ weeks). This can be attributed to the fact that in nullipara women, had higher incidence of oligohydramnios, incompetent cervix, hypertension in pregnancy, and eclampsia. Hence, this increased the frequency of preterm

\section{Volume 6 Issue 7, July 2017 www.ijsr.net}




\section{International Journal of Science and Research (IJSR) ISSN (Online): 2319-7064}

Index Copernicus Value (2015): 78.96 | Impact Factor (2015): 6.391

birth in nullipara when compared with multiparous women. $^{15}$

Table 4: Distribution of Preterm Labor Based on Gravida at RSUP Sanglah Denpasar period 1 January - 31 December 2016

\begin{tabular}{|c|c|c|}
\hline Gravida & $\mathbf{N}$ & $\mathbf{\%}$ \\
\hline Primigravida & 83 & 42.5 \\
\hline Gravida 2 & 55 & 28.2 \\
\hline Gravida 3 & 36 & 18.4 \\
\hline Gravida $\geq 4$ & 21 & 10.7 \\
\hline Total & $\mathbf{1 9 5}$ & $\mathbf{1 0 0}$ \\
\hline
\end{tabular}

Characteristics of Preterm Labor Based on Past Preterm Birth History

A total of 22 mothers had a history of preterm labor before, out of which 19 people $(6.9 \%)$ had experienced preterm labor once and 3 people had twice preterm labour other than the current pregnancy $(1.1 \%)$. A research conducted by Halimi in 2015 in Tehran, Iran found that $63.6 \%$ had experienced preterm labor from previous pregnancies and $49.2 \%$ had never experienced preterm labor before. ${ }^{8}$ In a study conducted by Paembonan et al in 2011 to 2012 at Makassar mentions that the history of preterm birth is a risk factor for preterm delivery with OR $=20,054 .{ }^{12}$ The results of this study are in line with Zhang's 2012 study, which states that mothers with a history of preterm labor are at risk 20,888 times for preterm delivery. ${ }^{10}$ Pregnant women who had a history of preterm labor 1 times had a probability to give birth to a premature baby of $14.3 \%$ and increased to $28.1 \%$ in women with a history of preterm delivery twice. ${ }^{10}$

Table 5: Distribution of Preterm Labor Based on History of Preterm Births Previously at RSUP Sanglah Denpasar period 1 January - 31 December 2016

\begin{tabular}{|c|c|c|}
\hline History of preterm labour & $N$ & $\%$ \\
\hline Once & 19 & 6.9 \\
\hline Twice & 3 & 1.1 \\
\hline Never & 173 & 88.7 \\
\hline Total & $\mathbf{1 9 5}$ & $\mathbf{1 0 0}$ \\
\hline
\end{tabular}

\section{Characteristics of Preterm Labor Based on Medical Disease}

From this research data obtained some medical illness that accompanied preterm labor. From the medical illness, the most common was hypertension with 49 cases $(25,1 \%)$ and anemia with 22 cases $(11.2 \%)$, and the least frequent was DHF with 1 case $(0.5 \%)$.

Similar to the research conducted by Halimi in 2015 in Tehran, Iran, which found that preterm labor is also accompanied with hypertension (ranked $72.3 \%$,) followed by anemia of $48.3 \%{ }^{8}$ Hypertension in pregnancy is closely related to the incidence of preterm labor. Hypertension in pregnancy causes the highest incidence of preterm labor based on research conducted by Rao in 2013 in India with preterm birth rates with hypertension in pregnancy of $21.4 \% .^{11}$
Table 6: Distribution of Preterm Labor Based on Medical Disease at RSUP Sanglah Denpasar period 1 January - 31 December 2016

\begin{tabular}{|c|c|c|}
\hline Medical conditions & $N$ & $\%$ \\
\hline Gestational hypertension & 49 & 25.1 \\
\hline Anemia & 22 & 11.2 \\
\hline Thrombocytopenia & 3 & 1.5 \\
\hline Diabetes mellitus & 2 & 1 \\
\hline Asthma & 2 & 1 \\
\hline Cardiac illness & 7 & 3.5 \\
\hline Malignancy & 4 & 2 \\
\hline Dengue hemorrhagic fever & 1 & 0.5 \\
\hline Urinary tract infection & 2 & 1 \\
\hline HIV & 4 & 2 \\
\hline Without medical condition & 99 & 50.7 \\
\hline Total & $\mathbf{1 9 5}$ & $\mathbf{1 0 0}$ \\
\hline
\end{tabular}

This may be due to many preeclampsia conditions related to the termination action Pregnancy before term as a result of complications.

\section{Characteristics of Preterm Labor Based on the Body Mass Index}

The body mass index (BMI) of women during pregnancy is influenced by genetic factors and also the nutritional component of the pregnant woman. Women with less BMI have less capacity for fluid expansion during pregnancy, whereas weight gain increases the reserves of maternal fat and nutrients, growth of uterine and breast tissue, and affects the growth of fetus. There are several hypotheses to the etiology and medical complications that can affect weight gain during pregnancy, namely the presence of diseases such as diabetes, hypertension, and polyhydramnios. Hence, the presence of these abnormalities increases the risk of preterm delivery. In addition, low BMI also increases levels of neutrophils and higher vaginal $\mathrm{pH}$, both of which increase the risk of preterm labor. ${ }^{13}$

Table 7: Distribution of Preterm Labor Based on the BMI at RSUP Sanglah Denpasar from 1st - 31st December, 2016

\begin{tabular}{|c|c|c|}
\hline BMI & $N$ & $\%$ \\
\hline Underweight & 14 & 7.1 \\
\hline Normal & 178 & 91.2 \\
\hline Overweight & 2 & 1 \\
\hline Obese grade I & 1 & 0.5 \\
\hline Obese grade II & 0 & 0 \\
\hline Obese grade III & 0 & 0 \\
\hline Total & $\mathbf{1 9 5}$ & $\mathbf{1 0 0}$ \\
\hline
\end{tabular}

Normal BMI of mother is the most common with as much as 178 cases(91.2\%), 14 (7.1\%) with underweight, and 2 people $(1.0 \%)$ with overweight.

Based on a study with 200 pregnant women, 34.5\% of spontaneous preterm delivery occurred in women with BMI $<19 \mathrm{~kg} / \mathrm{m}^{2}$, followed by $28.5 \%$ in normal BMI (19-24.9 $\left.\mathrm{kg} / \mathrm{m}^{2}\right), 21 \%$ of BMI $25-29.9 \mathrm{~kg} / \mathrm{m}^{2}, 14 \%$ in women with BMI $30-34.9 \mathrm{~kg} / \mathrm{m}^{2}$, and only $2 \%$ with BMI categories above $35 \mathrm{~kg} / \mathrm{m}^{2}$. So it can be concluded that the rate of spontaneous preterm labor decreases progressively compared with an increase in BMI. In addition, women with lower BMI tend to have preterm labor at earlier gestational age compared with obese women, of which $42.3 \%$ of women are not obese at 


\section{International Journal of Science and Research (IJSR) \\ ISSN (Online): 2319-7064}

Index Copernicus Value (2015): 78.96 | Impact Factor (2015): 6.391

preterm delivery at 30 weeks of gestation, whereas only $25 \%$ are in obese category. ${ }^{13}$

\section{Characteristics of Preterm Birth Based on Birth Weight}

The weight of preterm-born babies is divided into three groups: 500 grams to $<1000$ grams, 1000 grams to $<1500$ grams, 1500 grams to $<2500$ grams. Based on this study, out of a total of 195 deliveries, there were 17 cases of gemelli labor and 1 case of triplet birth, bringing the total number of babies born to 214 babies from 195 deliveries. The highest number of infants born between 1500 and $<2500$ grams was $164(84.1 \%)$, while 39 were born between 1000 and 1500 grams $(20 \%)$ and 11 babies $(5.6 \%)$. Weight $<1000$ grams. A study conducted by Butali et al in 2015 in Nigeria found that babies with birth weight $<1500$ grams of $20.9 \%$, and birth weight ranging from 1500 to $<2500$ grams by $41.8 \% .^{7}$ In 2012, a study in United States of America, found incidence of preterm infants birth as much as $11.55 \%$, of which $7.9 \%$ were of low birth weight. In addition, $2 \%$ of babies were born at very young pregnancies, and $1.42 \%$ with very low birth weight babies. Several hypotheses linking preterm birth and birth weight are associated with increased obstetric intervention, maternal age, fertility treatment in which it increases the incidence of multiple pregnancies.

Table 8: Distribution of Preterm Labor Based on Birth Weight Born in RSUP Sanglah Denpasar period 1 January 31 December 2016

\begin{tabular}{|c|c|c|}
\hline Birth weight & $N$ & $\%$ \\
\hline 500 up to < 1000 gram & 11 & 5.6 \\
\hline 1000 up to < 1500 gram & 39 & 20 \\
\hline 1500 up to < 2500 gram & 164 & 84.1 \\
\hline Total & $\mathbf{2 1 4}$ & $\mathbf{1 0 0}$ \\
\hline
\end{tabular}

\section{Characteristics of Preterm Labor Based on Newborn Infant Condition}

The American Association of Obstetrics and Gynecology and the American Academy of Pediatrics states that asphyxia is: 1 . umbilical artery $\mathrm{pH}<7.0,2$. Apgar score $0-3$ in the first 5 minutes, 3 . Neonatal neurologic manifestations (seizures, coma, or hypotonia) and 4. Dysfunction of multiple organ systems (cardiovascular, gastrointestinal, hematologic, pulmonary, or renal). Such preterm infants are also at higher risk for neonatal deaths associated with asphyxia. ${ }^{1}$

Based on this research, there are 214 babies delivering vigorous infant outbreaks (70\%), while moderate asphyxia is $17.2 \%$, weight of asphyxia is $4.2 \%$, and infant dies 18 (8.4 $\%)$.

Table 9: Distribution of Preterm Labor Based on Newborn Infant Condition at RSUP Sanglah Denpasar period 1 January - 31 December 2016

\begin{tabular}{|c|c|c|}
\hline Neonatal Asphyxia & $N$ & $\%$ \\
\hline Vigorous & 150 & 70 \\
\hline Moderate asphyxia & 37 & 17.2 \\
\hline Severe asphyxia & 9 & 4.2 \\
\hline Death & 18 & 8.4 \\
\hline Total & $\mathbf{2 1 4}$ & $\mathbf{1 0 0}$ \\
\hline
\end{tabular}

Characteristics of Preterm Labor by Type of Newborn Infant Care

Table 10: Distribution of Preterm Labor Based on Type of Newborn Baby Care at RSUP Sanglah Denpasar from 1st January to 31st December 2016

\begin{tabular}{|c|c|c|}
\hline Type of Medical care & $N$ & $\%$ \\
\hline Joint care & 167 & 78 \\
\hline NICU & 29 & 13.5 \\
\hline Death & 18 & 8.4 \\
\hline Total & $\mathbf{2 1 4}$ & $\mathbf{1 0 0}$ \\
\hline
\end{tabular}

Babies born preterm and treated in NICU was as many as 29 babies (13.5\%), while $167(78.0 \%)$ received rest of hospitalized. Almost all babies treated at the NICU had respiratory distress syndrome caused by early onset sepsis. The incidence of neonatal sepsis in developing countries is still high, the number of 1.8 to $18 / 1000$ births compared with developed countries is $1-5 / 1000$ births with mortality 5\% $20 \%$. In Alaska, death due to neonatal sepsis is most often caused by prematurity and very low birth weight. At Cipto Mangunkusumo Hospital, Jakarta, the incidence of neonatal sepsis is still high at $13.7 \%$ with a mortality rate of $14 \%$. In very low birth weight newborn, the incidence of early-onset sepsis occurs in $26 / 1000$ births as well as in premature infants. Early diagnosis of sepsis is a critical factor in the successful management of neonatal sepsis. Sepsis is diagnosed based on the presence of clinical symptoms such as lethargy, decreased suction reflex, moaning, seizures, respiratory distress and CRP levels $>10 \mathrm{mg} / \mathrm{L}$ caused by some risk factors including very low birth weight and preterm delivery in addition to premature rupture or chorioamnionitis. $^{14}$

\section{Conclusions}

In the 1 year period from 1 January to 31 December 2016, there was a preterm birth case in the midwifery emergency room of Sanglah General Hospital Denpasar Hospital as many as 195 cases (18.6\%) of all deliveries. The most frequent case of preterm birth occurred when the age of mother was between $20-35$ years $(77.9 \%)$. The most common age of pregnancy was 32 to $<37$ weeks $(67.6 \%)$. The most frequent method was spontaneous vaginal delivery (58.9\%). Preterm birth occured mostly in mothers with primigravida $(42.5 \%)$. The frequency of women with experience in preterm labor is 22 cases, of which19 cases $(9.7 \%)$ had twice and delivery and $3(1,5 \%)$ the rest had a history of 2 previous preterm deliveries. Hypertension was the most commonly medical condition that a company would set it required as much as 49 cases $(25,1 \%)$ submitted. The BMI of woman who had preterm labor at Sanglah was mostly in normal category at as many as 178 cases $(91.2 \%)$. Most preterm babies weight between 1500 to <2500 grams. Most babies born preterm were likely to be born in vigorous condition (70\%). There were 167 infants (78\%) who were born preterm in Sanglah Hospital, from January 1 to December 31, 2016 treated for joint, and the remaining 29 $(13.5 \%)$ were admitted to the NICU. 


\section{International Journal of Science and Research (IJSR) \\ ISSN (Online): 2319-7064 \\ Index Copernicus Value (2015): 78.96 | Impact Factor (2015): 6.391}

\section{Recommendation}

This research is a preliminary research that can be used as reference data about the characteristics of preterm labor in obstetrics and obstetric diseases RSUP Sanglah Denpasar during January 1 - December 31, 2016 period. Considering the importance of the data and this research is the basic data it is necessary to be done continuously to know all the characteristics that have been described with the occurrence of preterm birth and its complications so that in the future, it can be used as a consideration for preterm labor management and reduce and anticipate the complications that can happen

\section{References}

[1] Lee AC, Katz J, Blencowe H, Cousens S, Kozuki N, Vogel JP, Christian P. National and regional estimates of term and preterm babies born small for gestational age in 138 low-income and middle-income countries in 2010. The Lancet Global Health; 2013. 1(1), e26-e36.

[2] Chandiramani M, Tribe RM, Shennan AH. Preterm Labour And Prematurity. Obstetric Gynaecology And Reproductive Medicine; 2007. 17(8): 232-7.

[3] HKFM. Panduan pengelolaan Persalinan Preterm Nasional. Himpunan Kedokteran Fetomaternal POGI; 2011.

[4] Dinas Kesehatan Provinsi Bali. Profil Kesehatan Provinsi Bali Tahun 2011. 2012. 3: p. 14-6.

[5] Handono B. Mekanisme Persalinan Prematur. Prematuritas. 2009. p. 19-42.

[6] Blencowe H, Cousens S, Oestergaard MZ, Chou D, Moller AB, Narwal R, Lawn JE. National, regional, and worldwide estimates of preterm birth rates in the year 2010 with time trends since 1990 for selected countries: a systematic analysis and implications. The Lancet; 2012. 379(9832), p. 2162-72.

[7] Butali A, Ezeaka C, Ekhaguere O, Weathers N, Ladd J, Fajolu I, Adeyemo W. Characteristics and risk factors of preterm births in a tertiary center in Lagos, Nigeria. Pan African Medical Journal; 2016. 24(1).

[8] Halimi AA, Safari, S, Parvareshi HM. Epidemiology and Related Risk Factors of Preterm Labor as an obstetrics emergency. Tehran, Emergency; 2017.5(1), e3.

[9] Van den Broek NR, White SA, Goodall M, Ntonya C, Kayira E, Kafulafula G, Neilson JP. The APPLe study: a randomized, community-based, placebo-controlled trial of azithromycin for the prevention of preterm birth, with meta-analysis. PLoS Med; 2009. 6(12), e1000191.

[10]Zhang YP, Liu XH, Gao SH, Wang JM, Gu YS, Zhang JY, Li QX. Risk factors for preterm birth in five Maternal and Child Health hospitals in Beijing. PloS one; 2012. 7(12), e52780.

[11] Rao CR, de Ruiter LE, Bhatamath V, Kamath A, Bhat V. A case-control study on risk factors for preterm deliveries in a secondary care hospital, southern India. ISRN obstetrics and gynecology; 2014.

[12] Paembonan N, Ansar J, Arsyad DS. Faktor risiko kejadian kelahiran prematur di rumah sakit ibu dan anak Siti Fatimah Kota Makassar. 2014.
[13] Al-Salami KS, Alyasin ZT, Husain RN. Influence of body mass index on the insidence of preterm labour. Bas J Surg; 2009

[14] Wilar R, Kumalasari E, Suryanto DY, Gunawan S. Faktor risiko sepsis awitan dini. Sari pediatri; 2010. 12(4), 265-8.

[15] James S, Gil KM, Meyers NA, Stewart J. Effect of parity on gestational age at delivery in multiole gestation pregnancies. Journal of Perinatology; 2009

Volume 6 Issue 7, July 2017 www.ijsr.net 